\title{
Improved Synthesis of the Antitubercular Agent SQ109
}

\section{Marianna Stampolaki ${ }^{1}$ \\ Antonios Kolocouris* (D)}

Laboratory of Medicinal Chemistry, Section of Pharmaceutical Chemistry, Department of Pharmacy, National and Kapodistrian University of Athens, Panepistimioupolis-Zografou, 15771 Athens, Greece

ankol@pharm.uoa.gr

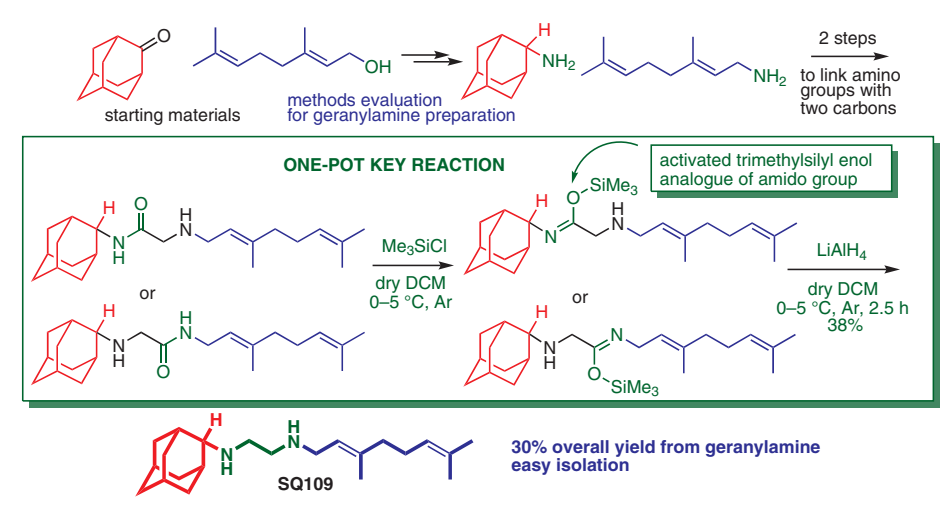

Received: 10.08 .2021

Accepted after revision: 27.09.2021

Published online: 27.09 .2021

DOI: 10.1055/a-1655-5867; Art ID: so-2021-d0041-I

License terms: $(c)(1) \ominus$

(c) 2021. The Author(s). This is an open access article published by Thieme under the terms of the Creative Commons Attribution-NonDerivative-NonCommercial-License, permitting copying and reproduction so long as the original work is given appropriate credit. Contents may not be used for commercial purposes or adapted, remixed, transformed or built upon. (https://creativecommons.org/licenses/by-nc-nd/4.0/)

Abstract We present here an improved procedure for the preparation of the promising antitubercular drug SQ109 that is currently in phase Ib/III of clinical trials against Mycobacterium tuberculosis. We investigated and tested the literature synthetic procedure that enables the development of structure-activity relationships and report the observed inconsistencies as well as presenting improvements or novelties for the more efficient preparation of SQ109. Most significantly we applied a novel reduction step of the aminoamide precursor using $\mathrm{Me}_{3} \mathrm{SiCl} / \mathrm{LiAlH}_{4}$ under mild conditions. These findings are important for research groups investigating the efficacy of this drug and analogues in academia and industry.

Key words SQ109, tuberculosis, synthesis, reduction, trimethylsilyl chloride, geranylamine, lithium aluminum hydride

Tuberculosis (TB) remains the most lethal disease worldwide, caused by the bacillus of Mycobacterium tuberculosis (Mtb). An estimated 10 million people fall ill with TB every year and it is a leading infectious agent for carriers of HIV. ${ }^{2}$ Several compounds have been developed as antitubercular agents and $N$-geranyl- $N^{\prime}$-(2-adamantyl)ethane-1,2-diamine $(\mathrm{SQ} 109, \mathbf{1 0})^{3,4}$ is a promising second-generation ethylenediamine agent after the first-line-drug ethambutol (Figure 1). ${ }^{5}$ SQ109 (10) blocks an essential step of the synthesis of the mycobacterial outer membrane, via direct or indirect inhibition of MmpL3 transporter of trehalose monomycolate (TMM), ${ }^{6-10}$ which is a basic component of the mycobacterial cell envelope. ${ }^{9,11,12}$ SQ109 (10) is in phase IIb/III of clinical trials showing high potency against resis- tant Mtb strains and other pathogens. ${ }^{13-15}$ The importance of SQ109 (10) has triggered interest into the synthesis of analogues ${ }^{5,6,16-19}$ aiming at the improvement of potency and pharmacokinetic properties.

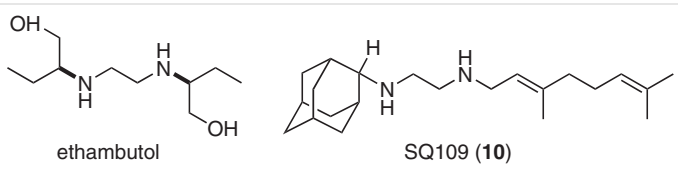

Figure 1 Chemical structures of ethambutol and SQ109 (10)

The reported methods for the synthesis of SQ109 (10) couple geranylamine 4 with 2-adamantanamine (6) through an ethylenediamine linker and include condensation of one of these amines ${ }^{5,16-18}$ with chloroacetyl chloride ${ }^{5}$ or bromoacetyl chloride, ${ }^{16-18}$ following a condensation reaction with the second amine, and then reduction of the amide group of the two carbon linker with $\mathrm{LiAlH}_{4}$ in refluxing tetrahydrofuran (THF) ${ }^{16-18}$ or with Red-Al in THF under reflux ${ }^{16}$ or room temperature. ${ }^{5}$ Alternatively, condensation of 2-adamantanone with $\mathrm{N}$-geranyl ethylenediamine (prepared from geranyl bromide $\mathbf{2}$ and ethylenediamine) is followed by reductive amination with $\mathrm{NaBH}_{4}$ in methanol. ${ }^{17,18}$ This procedure is much more convenient and can be applied to the synthesis of SQ109 analogues having a second substituent, such as an alkyl group, at the 2-adamantyl position.

The preparation of geranylamine $\mathbf{4}$ has been reported using the low-cost precursor geraniol (1) and phthalimide, which were subjected to a Mitsunobu reaction to afford $N$ geranyl-phthalimide. ${ }^{16,20}$ Geraniol (1) can also be converted quantitatively into geranyl bromide $(2)^{17,18}$ that can be reacted with potassium phthalimide using the Gabriel reaction $^{17,18,20,21}$ or with phthalimide under microwave conditions, ${ }^{22}$ affording $N$-geranyl phthalimide (Schemes 1 and 2 ). 
The $N$-geranyl phthalimide is then treated with an aqueous solution of hydrazine $60 \% \mathrm{w} / \mathrm{v}$ to afford 4 (without chromatographical purification according to the literature) in $37-49 \%,{ }^{16} 69 \%,{ }^{20}$ or $62 \%{ }^{17,18}$ yield from geraniol (1) using the Mitsunobu or Gabriel reaction, respectively. In the original literature procedure we found geranylamine 4 was synthesized by Gabriel reaction in $20 \%$ yield from geranyl chloride $^{23}$ and $77 \%$ from geranyl bromide. ${ }^{17,18,20,21}$ Reduction of 1-geranylazide (5) with Lindlar catalyst has been reported as effective for the selective reduction of the azido group to an allylic azide. ${ }^{24}$ Additionally, the Staudinger reaction of geraniol acetate, ${ }^{25}$ using $\mathrm{PPh}_{3}$ and $\mathrm{NH}_{3}$ has been applied for the preparation of $\mathbf{4}$ in $59 \%$ yield.

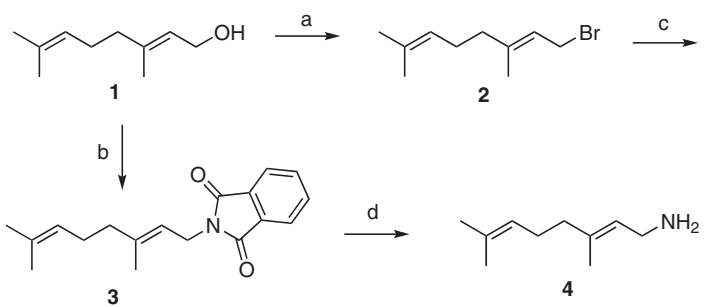

Scheme 1 Reagents and conditions: (a) $\mathrm{PBr}_{3}$, dry $\mathrm{Et}_{2} \mathrm{O},-5^{\circ} \mathrm{C}, 3 \mathrm{~h}$, (quant.); (b) $\mathrm{Ph}_{3} \mathrm{P}$, DIAD, phthalimide, anhydrous THF, rt, $24 \mathrm{~h}(81 \%)$; (c) phthalimide, $\mathrm{K}_{2} \mathrm{CO}_{3}$, anhydrous THF, reflux, $24 \mathrm{~h}$, (88\%); (d) $\mathrm{N}_{2} \mathrm{H}_{4} \cdot \mathrm{H}_{2} \mathrm{O}$, $\mathrm{EtOH}$, reflux, $6 \mathrm{~h}(81 \%)$.

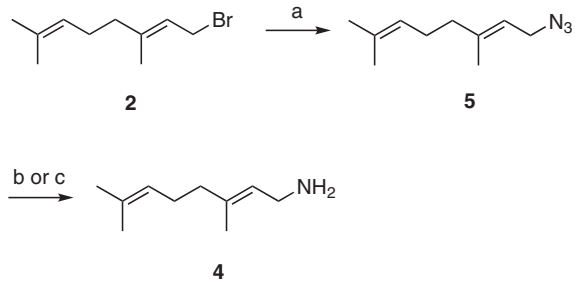

Scheme 2 Reagents and conditions: (a) $\mathrm{NaN}_{3}$, EtOH, reflux, $5 \mathrm{~h}(92 \%)$; (b) $\mathrm{PPh}_{3}, \mathrm{THF} / \mathrm{H}_{2} \mathrm{O}$, rt, $12 \mathrm{~h}$ (34\%); (c) $\mathrm{LiAlH}_{4}$, anhydrous Et $\mathrm{O}, \mathrm{rt}, 24 \mathrm{~h}$ (24\%).

We managed to synthesize and test the anti-Mtb activity of SQ109 (10) and analogues according to the first of the above-mentioned procedures for SQ109 (10) preparation, ${ }^{5,16-18}$ which also enables the preparation of analogues substituted at the 2-adamantyl position. We report herein our observations of inconsistencies and improvements regarding previously reported results.

We firstly describe our observations during preparation of the commercially available but expensive geranylamine 4. We reacted geraniol (1) with phosphorus tribromide in dry diethyl ether at $-5{ }^{\circ} \mathrm{C}$ and obtained geranyl bromide 2 in 99.5\% yield (Scheme 1), which was converted into $\mathrm{N}$-geranyl phthalimide 3 using both the Mitsunobu reaction at room temperature ${ }^{16,20}$ or Gabriel reaction under reflux. ${ }^{17,18,20,21}$ Hydrazinolysis of $N$-geranyl phthalimide ${ }^{16-18,20}$ under refluxing conditions afforded geranylamine $\mathbf{4}$ in $81 \%$ yield. During workup use of aqueous hydrochloric acid should be avoided since the double bond at 6-position of geranylamine 4 reacts, as evidenced by the observation of a singlet at $\delta=1.19 \mathrm{ppm}$ in the ${ }^{1} \mathrm{H}$ NMR spectrum, which is attributed to a $t$-Bu group, and the disappearance of the unsaturated $\mathrm{CH}$ proton resonance at ca. $\delta=5 \mathrm{ppm}$ leading to a secondary amine contamination of the product.

We also tested the reaction of geranyl bromide $\mathbf{2}$ with sodium azide in refluxing ethanol to afford geranylazide $\mathbf{5}$ in $92 \%$ yield. We then examined reduction of 1-geranylazide (5) by Staudinger reaction, ${ }^{26,27}$ using $\mathrm{PPh}_{3}$ in $\mathrm{THF} / \mathrm{H}_{2} \mathrm{O}(10: 1)$ and isolated geranylamine 4 in 34\% yield as a solid hydrochloride salt (Scheme 2). We were not able to improve the yield and did not isolate any other amine side product. However, we observed minor peaks in the ${ }^{1} \mathrm{H}$ NMR spectrum of geranylazide. It has been shown ${ }^{25}$ that geranylazide is in equilibrium with linalyl azide in a ratio of ca. 80:20, as is shown in the spectrum of geranylazide in the Supporting Information. Perhaps, the equilibrium between geranylazide and linalyl azide of different stability (the last having a tertiary carbon azide bond) is the reason for the low yield of geranylamine $\mathbf{4}$ which is formed through the corresponding triphenyl( $N$-geranylimino)phosphorane. This may the reason why the authors ${ }^{25}$ improved the Staudinger reaction conditions using geranyl acetate and $\mathrm{Ph}_{3} \mathrm{P} / \mathrm{NH}_{3}$ to obtain geranylamine 4 in 59\% yield. However, we did not apply these reaction conditions since we obtained geranylamine 4 in a better yield using a procedure using Mitsunobu or Gabriel conditions as described above.

Next, we examined the reduction of 1-geranylazide (5) with $\mathrm{LiAlH}_{4}$ at room temperature and obtained geranylamine 4 as the free amine in $24 \%$ yield. It should be borne in mind that the Staudinger reaction has the disadvantage of the need to remove the phosphine oxide side product from the resulting reaction mixture.

We then proceeded to the connection of geranylamine 4 and commercially available 2 -adamantanamine (6, alternatively prepared by reduction of the oxime of 2-adamantanone ${ }^{28}$ with $\mathrm{LiAlH}_{4}$, see the Supporting Information) through the two-methylene linker (Scheme 3). We treated either 2-adamantanamine (6) or geranylamine 4 with a mixture of 1-bromoacetylcloride and potassium carbonate at room temperature and produced the corresponding bromoacetamides $\mathbf{7}$ or $\mathbf{1 1}$ in $83 \%$ or $91 \%$ yield, respectively (Scheme 3). Subsequently, adding solution of $\mathbf{7}$ or $\mathbf{1 1}$ in dry THF to a solution of geranylamine $\mathbf{4}$ or 2-adamantanamine (6) and triethylamine in dry THF at room temperature furnished $\mathbf{8}$ or 12, which are aminoamide precursors of SQ109 (10), in $86 \%$ or $72 \%$ yield, respectively.

We applied the literature conditions for the reduction of aminoamide 8, which involves the reaction with $\mathrm{LiAlH}_{4}$ in refluxing dry THF under inert atmosphere for 16 h. ${ }^{6,17,19} \mathrm{Al}-$ though it was reported that this reduction yielded SQ109 (10) in 50\% yield after column chromatography, our two repeats afforded SQ109 (10) in 8\% and 14\% yield after column 


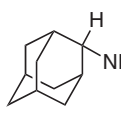

6

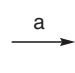<smiles>O=C(CBr)NC1C2CC3CC(C2)CC1C3</smiles>

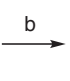<smiles>NCC(=O)NC1C2CC3CC(C2)CC1C3</smiles>

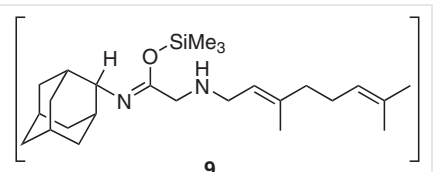
$\downarrow c$<smiles>CC(C)=CCC/C(C)=C/CNCCNC1C2CC3CC(C2)CC1C3</smiles>

SQ109 (10)
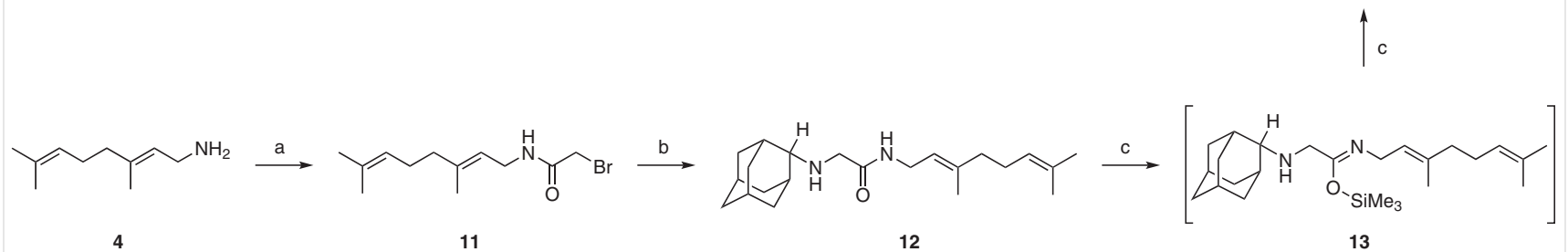

4

11

12

13

Scheme 3 Synthesis of SQ109. Reagents and conditions: (a) $\mathrm{ClCOCH}_{2} \mathrm{Br}, \mathrm{K}_{2} \mathrm{CO}_{3}$ (aqueous), DCM, rt, $24 \mathrm{~h}$ (7: 83\%, 11: 91\%); (b) 4 or 6, Et ${ }_{3} \mathrm{~N}$, dry THF, rt, 48 h, (8: 86\%, 12: 72 \%); (c) (i) $\mathrm{Me}_{3} \mathrm{SiCl}$, $\mathrm{LiAlH}_{4}$, dry DCM, 0-5 ${ }^{\circ} \mathrm{C}$, Ar, 2.5 h; (ii) $\mathrm{NaOH} 10 \%, 0{ }^{\circ} \mathrm{C}(31-38 \%)$.

chromatography. We also observed the formation of geranylamine $\mathbf{4}$ and a byproduct formed due to the partial reduction of the geranyl chain since the double bond close to the reaction center becomes saturated. This is evidenced immediately by the disappearance of the corresponding unsaturated $\mathrm{CH}$ proton resonance at $\delta=5.25 \mathrm{ppm}(\mathrm{m})$ in the ${ }^{1} \mathrm{H}$ NMR spectrum. Additionally, an aqueous hydrochloride solution should not be used during reaction workup since, as mentioned previously, we observed that the distant double bond from the reaction center becomes saturated. We also tested the reduction with $\mathrm{LiAlH}_{4}$ in dry tetrahydrofuran or diethyl ether at room temperature, but we obtained again the same mixture of amines.

We then explored more selective reduction conditions of the amido group and examined the use of $\mathrm{Me}_{3} \mathrm{SiCl} / \mathrm{LiAlH}_{4}{ }^{29}$ (see experimental section in ref. 17) This reagent can activate the amide carbonyl functionality through the formation of the trimethylsilyl enol intermediates 9 or $\mathbf{1 3}$ (Scheme 3); the in situ generated imine $\mathbf{9}$ or $\mathbf{1 3}$ being reduced efficiently with $\mathrm{LiAlH}_{4}$ to the amino group under mild conditions. Thus, when we treated aminoamides 8 or 12 with a mixture of $\mathrm{LiAlH}_{4}$ and distilled $\mathrm{Me}_{3} \mathrm{SiCl}$ in dry dichloromethane (DCM) at $0-5{ }^{\circ} \mathrm{C}$ for $2.5 \mathrm{~h}$ under an inert atmosphere, we isolated SQ109 (10) in 31-38\% yield after column chromatography (Scheme 3). Increasing the reaction time or temperature to gentle reflux did not improve the yield of SQ109 (10).

The yield for converting geraniol (1) into geranylamine 4 was $20 \%$ in ref. 17 and $37 \%$ in ref. 16 compared to $66 \%$ in our work. The overall yield for SQ109 (10) starting from geraniol (1) in ref. 17 is $5 \%$ and in ref. 16 is $16 \%$ compared to our ca. $20 \%$ yield. The yield for SQ109 (10) synthesis in ref. 5 was reported to be $24 \%$ from geranylamine 4 , or the overall yield from geraniol (1) was ca. 5-8\% (based on the yields for converting geraniol (1) into geranylamine (4) using the Gabriel ${ }^{17}$ or Mitsunobu reaction ${ }^{16}$ reported in ref. 17 and 16, respectively).

The yield of a second reported procedure including the condensation of 2-adamantanone with $\mathrm{N}$-geranyl ethylenediamine (prepared from geranyl bromide $\mathbf{2}$ and ethylenediamine), followed by reductive amination with $\mathrm{NaBH}_{4}$ in methanol, ${ }^{17,18}$ is $18 \%$ from geranyl bromide 2 , and the overall yield from geraniol (1) is $17 \%$. However, as mentioned, this procedure is not general for SQ109 (10) analogues with a second substituent at 2-adamantyl group position.

In conclusion, SQ109 (10) is currently in phase Ib/III of clinical trials against Mycobacterium tuberculosis. Herein, we report our investigations into the literature procedures for the synthesis of SQ109 (10) that enables the development of structure-activity relationships through the preparation of SQ109 (10) analogues at 2-adamantyl position. ${ }^{30}$ We report inconsistencies and improvements for the more efficient preparation of important intermediates such as geranylamine $\mathbf{4}$ and the reduction of aminoamides $\mathbf{8}$ or $\mathbf{1 2}$ leading to SQ109 (10). Thus, while we used both 2-adamantanamine (6) and geranylamine $\mathbf{4}$ as the first or second amine shown in Scheme 3, we found that the reduction of the amide bond in the intermediate aminoamide $\mathbf{8}$ or $\mathbf{1 2}$, respectively, is problematic, yielding a mixture of amines, due to decomposition of the substrate and partial reduction of the geranyl chain, significantly lowering the yield of SQ109 (10). We identified that the application of $\mathrm{Me}_{3} \mathrm{SiCl} /$ $\mathrm{LiAlH}_{4}$ under mild conditions can be used for the efficient reduction of the aminoamide precursors $\mathbf{8}$ or $\mathbf{1 2}$ to SQ109 
(10). The findings will hopefully assist in the investigation of the efficacy of SQ109 (10) and analogues with potentially improved pharmacokinetic properties.

\section{Conflict of Interest}

The authors declare no conflict of interest.

\section{Funding Information}

Chiesi Hellas (grant number 10354).

\section{Acknowledgment}

We thank Andreea-Larissa Turcu in Santiago Vazquez lab for obtaining the HR-MS spectra.

\section{Supporting Information}

Supporting Information includes NMR spectra of intermediates and SQ109.Supporting information for this article is available online at https://doi.org/10.1055/a-1655-5867.

\section{References and Notes}

(1) This research is part of the PhD thesis of M.S

(2) (a) Fogel, N. Tuberculosis 2015, 95, 527. (b) Furin, J.; Cox, H.; Pai, M. Lancet 2019, 393, 1642 .

(3) Mdluli, K.; Kaneko, T.; Upton, A. Cold Spring Harb. Perspect. Med. 2015, 5, a021154.

(4) Vasava, M. S.; Nair, S. G.; Rathwa, S. K.; Patel, D. B.; Patel, H. D. Indian J. Tuberc. 2019, 66, 12.

(5) Lee, R. E.; Protopopova, M.; Crooks, E.; Slayden, R. A.; Terrot, M.; Barry, C. E. J. Comb. Chem. 2003, 5, 172.

(6) Li, K.; Schurig-Briccio, L. A.; Feng, X.; Upadhyay, A.; Pujari, V.; Lechartier, B.; Fontes, F. L.; Yang, H.; Rao, G.; Zhu, W.; Gulati, A.; No, J. H.; Cintra, G.; Bogue, S.; Liu, Y.-L.; Molohon, K.; Orlean, P.; Mitchell, D. A.; Freitas-Junior, L.; Ren, F.; Sun, H.; Jiang, T.; Li, Y.; Guo, R.-T.; Cole, S. T.; Gennis, R. B.; Crick, D. C.; Oldfield, E. J. Med. Chem. 2014, 57, 3126.

(7) Zhang, B.; Li, J.; Yang, X.; Wu, L.; Zhang, J.; Yang, Y.; Zhao, Y.; Zhang, L.; Yang, X.; Yang, X.; Cheng, X.; Liu, Z.; Jiang, B.; Jiang, H.; Guddat, L. W.; Yang, H.; Rao, Z. Cell 2019, 176, 636.

(8) Su, C.-C.; Klenotic, P. A.; Bolla, J. R.; Purdy, G. E.; Robinson, C. V.; Yu, E. W. Proc. Natl. Acad. Sci. U.S.A. 2019, 116, 11241.

(9) Tahlan, K.; Wilson, R.; Kastrinsky, D. B.; Arora, K.; Nair, V.; Fischer, E.; Barnes, S. W.; Walker, J. R.; Alland, D.; Barry, C. E.; Boshoff, H. I. Antimicrob. Agents Chemother. 2012, 56, 1797.

(10) Xu, Z.; Meshcheryakov, V. A.; Poce, G.; Chng, S.-S. Proc. Natl. Acad. Sci. U.S.A. 2017, 114, 7993.

(11) Grzegorzewicz, A. E.; Pham, H.; Gundi, V. A. K. B.; Scherman, M. S.; North, E. J.; Hess, T.; Jones, V.; Gruppo, V.; Born, S. E. M.; Korduláková, J.; Chavadi, S. S.; Morisseau, C.; Lenaerts, A. J.; Lee, R. E.; McNeil, M. R.; Jackson, M. Nat. Chem. Biol. 2012, 8, 334.

(12) Belardinelli, J. M.; Yazidi, A.; Yang, L.; Fabre, L.; Li, W.; Jacques, B.; Angala, S. K.; Rouiller, I.; Zgurskaya, H. I.; Sygusch, J.; Jackson, M. ACS Infect. Dis. 2016, 2, 702.
(13) Veiga-Santos, P.; Li, K.; Lameira, L.; de Carvalho, T. M. U.; Huang, G.; Galizzi, M.; Shang, N.; Li, Q.; Gonzalez-Pacanowska, D.; Hernandez-Rodriguez, V.; Benaim, G.; Guo, R.-T.; Urbina, J. A.; Docampo, R.; de Souza, W.; Oldfield, E. Antimicrob. Agents Chemother. 2015, 59, 1950.

(14) Gil, Z.; Martinez-Sotillo, N.; Pinto-Martinez, A.; Mejias, F.; Martinez, J. C.; Galindo, I.; Oldfield, E.; Benaim, G. Parasitol. Res. 2020, 649.

(15) Sacksteder, K. A.; Protopopova, M.; Barry, C. E.; Andries, K.; Nacy, C. A. Future Microbiol. 2012, 7, 823.

(16) Meng, Q.; Luo, H.; Chen, Y.; Wang, T.; Yao, Q. Bioorg. Med. Chem. Lett. 2009, 19, 5372.

(17) Onajole, O. K.; Govender, P.; van Helden, P. D.; Kruger, H. G.; Maguire, G. E. M.; Wiid, I.; Govender, T. Eur. J. Med. Chem. 2010, 45, 2075.

(18) Onajole, O. K.; Belewa, X. V.; Coovadia, Y.; Govender, T.; Kruger, H. G.; Maguire, G. E. M.; Naidu, D.; Somai, B.; Singh, N.; Govender, P. Med. Chem. Res. 2011, 20, 1394.

(19) Li, K.; Wang, Y.; Yang, G.; Byun, S.; Rao, G.; Shoen, C.; Yang, H.; Gulati, A.; Crick, D. C.; Cynamon, M.; Huang, G.; Docampo, R.; No, J. H.; Oldfield, E. ACS Infect. Dis. 2015, 1, 215.

(20) Galaka, T.; Casal, M. F.; Storey, M.; Li, C.; Chao, M. N.; Szajnman, S. H.; Docampo, R.; Moreno, S. N. J.; Rodriguez, J. B. Molecules 2017, 22, 1.

(21) Shallu; Sharma, M. L.; Singh, J. J. Chem. Sci. 2014, 126, 1869.

(22) Dogra, S.; Sharma, M. L.; Singh, J. C. R. Chim. 2015, 18, 945.

(23) Bunton, C. A.; Hachey, D. L.; Leresche, J. P. J. Org. Chem. 1972, 37, 4036.

(24) Corey, E. J.; Nicolaou, K. C.; Balanson, R. D.; Machida, Y. Synthesis 1975, 590

(25) Murahashi, S.; Taniguchi, Y.; Imada, Y.; Tanigawa, Y.J. Org. Chem. 1989, 54, 3292.

(26) Gololobov, Y. G.; Zhmurova, I. N.; Kasukhin, L. F. Tetrahedron 1981, 37, 437.

(27) Bednarek, C.; Wehl, I.; Jung, N.; Schepers, U.; Bräse, S. Chem. Rev. 2020, $120,4301$.

(28) Kolocouris, A.; Tzitzoglaki, C.; Johnson, F. B.; Zell, R.; Wright, A. K.; Cross, T. A.; Tietjen, I.; Fedida, D.; Busath, D. D. J. Med. Chem. 2014, 57, 4629 .

(29) Ravinder, B.; Rajeswar Reddy, S.; Panasa Reddy, A.; Bandichhor, R. Tetrahedron Lett. 2013, 54, 4908.

(30) 1-Bromo-3,7-dimethylocta-2,6-diene (1-geranyl bromide, 2) A mixture of geraniol $(\mathbf{1}, 500 \mathrm{mg}, 3.24 \mathrm{mmol})$ and $\mathrm{PBr}_{3}(351 \mathrm{mg}$, $1.30 \mathrm{mmol}$ ) in anhydrous diethyl ether was stirred at $-5^{\circ}$ for 3 h. The resulting solution was extracted with $\mathrm{NaHCO}_{3} 5 \% \mathrm{w} / \mathrm{v}$ and brine. The organic extract was dried over $\mathrm{Na}_{2} \mathrm{SO}_{4}$ and evaporated in vacuo to give a yellow oil; yield $700 \mathrm{mg}(99.5 \%) .{ }^{1} \mathrm{H}$ NMR $\left(\mathrm{CDCl}_{3}, 400 \mathrm{MHz}\right): \delta=1.60(\mathrm{~s}, 3 \mathrm{H}, 8-\mathrm{H}), 1.68(\mathrm{~s}, 3 \mathrm{H}, 7-$ $\left.\mathrm{CH}_{3}\right), 1.73\left(\mathrm{~s}, 3 \mathrm{H}, 3-\mathrm{CH}_{3}\right), 2.08(\mathrm{~m}, 4 \mathrm{H}, 4-\mathrm{H}, 5-\mathrm{H}), 4.03(\mathrm{~d}, J=8.4$ $\mathrm{Hz}, 2 \mathrm{H}, 1-\mathrm{H}), 5.07(\mathrm{~m}, 1 \mathrm{H}, 6-\mathrm{H}), 5.53(\mathrm{t}, J=8.5 \mathrm{~Hz}, 1 \mathrm{H}, 2-\mathrm{H})$ ppm.

1-Phthalimido-3,7-dimethylocta-2,6-diene (1-geranyl phthalimide, 3)

A solution of geranyl bromide $(520 \mathrm{mg}, 2.40 \mathrm{mmol})$, phthalimide (353 mg, $2.40 \mathrm{mmol})$, and $\mathrm{K}_{2} \mathrm{CO}_{3}(994 \mathrm{mg}, 7.2 \mathrm{mmol})$ in anhydrous THF $(10 \mathrm{~mL})$ was heated to reflux overnight. The solvent was then evaporated in vacuo, water was added, and the mixture was extracted twice with diethyl ether. The combined organic extracts were dried over $\mathrm{Na}_{2} \mathrm{SO}_{4}$, filtered, and concentrated in vacuo. The crude product was purified by column chromatography using $n$-hexane/EtOAc $(15: 1)$ as eluent to afford geranyl phthalimide as a pale-yellow oil; yield $600 \mathrm{mg}$ (88\%). 
1-Amino-3,7-dimethylocta-2,6-diene (1-geranylamine, 4) Procedure A

A solution of geranyl phthalimide $(600 \mathrm{mg}, 2.12 \mathrm{mmol})$ and hydrazine monohydrate $(0.160 \mathrm{~mL}, 3.18 \mathrm{mmol}, 1.5$ equiv) in absolute EtOH $(10 \mathrm{~mL})$ was heated to reflux for $6 \mathrm{~h}$. The solvent was evaporated in vacuo, $15 \%$ aq. $\mathrm{NaOH}$ was added, and the mixture extracted twice with DCM. The combined organic phases were washed with water, dried over $\mathrm{Na}_{2} \mathrm{SO}_{4}$, filtered, and concentrated in vacuo. After column chromatography $81 \%$ of geranylamine $\mathbf{4}$ was obtained.

\section{Procedure B}

A mixture of azide 5 (240 mg, $1.34 \mathrm{mmol})$ and $\mathrm{PPh}_{3}(386 \mathrm{mg}$, $1.47 \mathrm{mmol})$ in THF/water $(10: 1,7 \mathrm{~mL})$ was stirred at room temperature for $12 \mathrm{~h}$. The solvent was evaporated under vacuum, and equal quantities of water $(20 \mathrm{~mL})$ and DCM $(20 \mathrm{~mL})$ were added for extraction. The organic solution was then washed with $\mathrm{HCl} 6 \% \mathrm{v} / \mathrm{v}$, the aqueous extract was made alkaline with solid $\mathrm{Na}_{2} \mathrm{CO}_{3}$ and extracted with DCM. After solvent evaporation in vacuo the crude amine product was obtained ( $90 \mathrm{mg}$ ). Anhydrous diethyl ether $(15 \mathrm{~mL})$ was added, and the organic solution was treated with a saturated solution of ethanol with hydrogen chloride at $0{ }^{\circ} \mathrm{C}$ to afford the hydrochloride salt as a white precipitate. After overnight cooling at $5{ }^{\circ} \mathrm{C}$ and suction filtration, geranylamine $\mathbf{4}$ hydrochloride was obtained as a white solid ( 87 $\mathrm{mg}, 34 \%$ yield).

\section{Procedure C}

To a suspension of $\mathrm{LiAlH}_{4}(152 \mathrm{mg}, 4.0 \mathrm{mmol})$ in anhydrous diethyl ether ( $8 \mathrm{~mL})$, a solution of azide 5 ( $480 \mathrm{mg}, 2.68 \mathrm{mmol}$ ) in anhydrous diethyl ether $(5 \mathrm{~mL})$ was added dropwise at $0{ }^{\circ}$. The mixture was left stirring at room temperature overnight and was quenched with water $(2 \mathrm{~mL}), 15 \% \mathrm{w} / \mathrm{v} \mathrm{NaOH}(2 \mathrm{~mL})$, and then water $(6 \mathrm{~mL})$ at $0^{\circ}$. The resulting inorganic precipitate was filtered off and washed thoroughly with diethyl ether. The filtrate was extracted twice with $\mathrm{HCl} 6 \% \mathrm{v} / \mathrm{v}$, and the aqueous phase was made alkaline with solid $\mathrm{Na}_{2} \mathrm{CO}_{3}$ and extracted twice with DCM. The combined organic extracts were washed with water and dried over solid $\mathrm{Na}_{2} \mathrm{SO}_{4}$. After filtration, the solvent was evaporated in vacuo to afford geranylamine $\mathbf{4}$ as a paleyellow oil (98 mg, 24\% yield). Hydrochloride salt: ${ }^{1} \mathrm{H}$ NMR $\left(\mathrm{CDCl}_{3}, 400 \mathrm{MHz}\right): \delta=1.60(\mathrm{~s}, 3 \mathrm{H}, 8-\mathrm{H}), 1.63\left(\mathrm{~s}, 3 \mathrm{H}, 7-\mathrm{CH}_{3}\right), 1.68$ (s, $\left.3 \mathrm{H}, 3-\mathrm{CH}_{3}\right), 1.97-2.07$ (m, $\left.4 \mathrm{H}, 4-\mathrm{H}, 5-\mathrm{H}\right), 3.30$ (d, J = 7.4 Hz, 2 $\mathrm{H}, 1-\mathrm{H}), 5.07-5.11(\mathrm{~m}, 1 \mathrm{H}, 6-\mathrm{H}), 5.26(\mathrm{t}, J=7.5 \mathrm{~Hz}, 1 \mathrm{H}, 2-\mathrm{H})$ ppm. ${ }^{13} \mathrm{C} \mathrm{NMR}\left(\mathrm{CDCl}_{3}, 150 \mathrm{MHz}\right): \delta=16.5\left(3-\mathrm{CH}_{3}\right), 18.0\left(7-\mathrm{CH}_{3}\right)$, 26.0 (8-C), 26.8 (5-C), 39.7 (4-C), 39.9 (1-C), 124.4 (2-C), 125.1 (6-C), $131.9(7-C), 137.5(3-C)$ ppm.

\section{1-Azido-3,7-dimethylocta-2,6-diene (1-geranylazide, 5)}

A mixture of bromide $\mathbf{2}(500 \mathrm{mg}, 2.30 \mathrm{mmol})$ and $\mathrm{NaN}_{3}(299 \mathrm{mg}$, $4.60 \mathrm{mmol})$ in ethanol $(7 \mathrm{~mL})$ was heated to reflux for $5 \mathrm{~h}$, the mixture was concentrated under reduced pressure, and water $(15 \mathrm{~mL})$ was added. The resulting solution was extracted with DCM $(2 \times 20 \mathrm{~mL})$ and the combined organic extracts were washed with brine, dried over $\mathrm{Na}_{2} \mathrm{SO}_{4}$, filtered, and evaporated in vacuo to afford a yellow oil; yield $380 \mathrm{mg}(92 \%) .{ }^{1} \mathrm{H}$ NMR $\left(\mathrm{CDCl}_{3}, 400 \mathrm{MHz}\right): \delta=1.61(\mathrm{~s}, 3 \mathrm{H}, 8-\mathrm{H}), 1.69\left(\mathrm{~s}, 3 \mathrm{H}, 7-\mathrm{CH}_{3}\right), 1.71$ $\left(\mathrm{s}, 3 \mathrm{H}, 3-\mathrm{CH}_{3}\right), 2.10(\mathrm{~m}, 4 \mathrm{H}, 4-\mathrm{H}, 5-\mathrm{H}), 3.76(\mathrm{t}, J=7.4 \mathrm{~Hz}, 2 \mathrm{H}, 1-$ H), 5.09 (m, $1 \mathrm{H}, 6-\mathrm{H}), 5.33$ (t, J = 7.5 Hz, $1 \mathrm{H}, 2-\mathrm{H}) \mathrm{ppm}$.

\section{2-Adamantanamine (6)}

A solution of 2-adamantanone $(3.0 \mathrm{~g}, 20 \mathrm{mmol})$ in ethanol (35 $\mathrm{mL}$ ) was heated at $70{ }^{\circ} \mathrm{C}$. To this solution an aqueous solution $(20 \mathrm{~mL})$ of $\mathrm{HCl} \cdot \mathrm{H}_{2} \mathrm{NOH}(2.08 \mathrm{~g}, 30.0 \mathrm{mmol})$ with solid $\mathrm{Na}_{2} \mathrm{CO}_{3}$ (3.82 g, $36.0 \mathrm{mmol}$ ) was added portion-wise at $70{ }^{\circ} \mathrm{C}$. The mixture was stirred at the same temperature for $10 \mathrm{~min}$, and the ethanol was evaporated under reduced pressure. The aqueous suspension was allowed to cool at room temperature, and the white solid of 2-adamantanone oxime was filtered off; yield $2.86 \mathrm{~g}(86 \%) .{ }^{1} \mathrm{H} \mathrm{NMR}\left(\mathrm{CDCl}_{3}, 400 \mathrm{MHz}\right): \delta=1.81-1.99(\mathrm{~m}$, $14 \mathrm{H}, 1,3,4,5,6,7,8,9,10$-adamantane $\mathrm{H}$ ) ppm.

To a suspension of $\mathrm{LiAlH}_{4}(1.97 \mathrm{~g}, 51.9 \mathrm{mmol})$ in anhydrous THF $(35 \mathrm{~mL})$ a solution of 2-adamantanone oxime $(2.86 \mathrm{~g}, 17 \mathrm{mmol})$ in anhydrous THF $(40 \mathrm{~mL})$ was added dropwise at $0{ }^{\circ} \mathrm{C}$, and the suspension was then heated to reflux and left overnight under stirring. The mixture was allowed to return to room temperature, then cooled at $0{ }^{\circ} \mathrm{C}$, and then water $(2 \mathrm{~mL}), \mathrm{NaOH} 15 \% \mathrm{w} / \mathrm{v}$ $(2 \mathrm{~mL})$, and water $(6 \mathrm{~mL})$ were added. The resulting inorganic precipitate was filtered off and washed thoroughly with diethyl ether. The filtrate was extracted twice with $\mathrm{HCl} 6 \% \mathrm{w} / \mathrm{v}$, the aqueous phase was made alkaline with solid $\mathrm{Na}_{2} \mathrm{CO}_{3}$ and extracted with DCM. The combined organic extracts were washed with water and dried over $\mathrm{Na}_{2} \mathrm{SO}_{4}$. After filtration, the DCM was evaporated in vacuo to afford a pale oil of 2-adamantanamine (6, $1.45 \mathrm{~g}, 56 \%$ yield). ${ }^{1} \mathrm{H} \mathrm{NMR}\left(\mathrm{CDCl}_{3}, 400 \mathrm{MHz}\right): \delta=$ $1.53(\mathrm{~d}, J=12 \mathrm{~Hz}, 2 \mathrm{H}, 4$ eq,9eq-adamantane $\mathrm{H}), 1.70-1.85$ (m, $10 \mathrm{H}, 1,3,5,7,6,8,10$-adamantane $\mathrm{H}), 1.99$ (d, $J=12 \mathrm{~Hz}, 2 \mathrm{H}$, 4ax,9ax-adamantane H), 2.22 (br s, $\left.2 \mathrm{H}, \mathrm{NH}_{2}\right), 3.02(\mathrm{~s}, 1 \mathrm{H}, 2-$ adamantane $\mathrm{H}$ ) ppm. ${ }^{13} \mathrm{C} \mathrm{NMR}\left(\mathrm{CDCl}_{3}, 50 \mathrm{MHz}\right): \delta=27.1$ (7-adamantane C), 28.0 (5-adamantane C), 31.1 (4,9-adamantane C), 35.1 (8,10-adamantane C), 38.0 (1,3-adamantane C), 38.3 (6adamantane C), 55.9 (2-adamantane $C$ ) ppm.

\section{$\mathbf{N}$-(2-Adamantanyl)-2-bromoacetamide (7)}

Bromoacetyl chloride (801 mg, $5.09 \mathrm{mmol})$ in DCM $(13 \mathrm{~mL})$ was added dropwise at $0{ }^{\circ} \mathrm{C}$ to a vigorously stirred suspension of 2adamantanamine $(6,700 \mathrm{mg}, 4.63 \mathrm{mmol})$ in DCM $(23 \mathrm{~mL})$ and $\mathrm{K}_{2} \mathrm{CO}_{3}(806 \mathrm{mg})$ and water $(8 \mathrm{~mL})$. The mixture was stirred for $24 \mathrm{~h}$, and then the aqueous phase was extracted twice with DCM. The combined organic extracts were evaporated in vacuo, and the crude product was dissolved in diethyl ether. The solution was washed sequentially with $\mathrm{NaHCO}_{3} 10 \% \mathrm{w} / \mathrm{v}$, water, $\mathrm{HCl}$ $3 \% \mathrm{v} / \mathrm{v}$, water, and brine. The solvent was then evaporated in vacuo, and the product was filtered through silica gel using $n$-hexane/EtOAc (3:1) as eluent to afford a white solid (1.05g, $83 \%$ yield ). ${ }^{1} \mathrm{H} \mathrm{NMR}\left(\mathrm{CDCl}_{3}, 400 \mathrm{MHz}\right): \delta=1.67(\mathrm{~d}, J=12 \mathrm{~Hz}, 2 \mathrm{H}$, 4eq,9eq-adamantane H), 1.75-1.93 (m, $10 \mathrm{H}, 1,3,5,7,6,8,10-$ adamantane $\mathrm{H}$ ), 2.04 (s, $2 \mathrm{H}, 4 \mathrm{ax}, 9 \mathrm{ax}$-adamantane $\mathrm{H}$ ), 3.91 (s, $2 \mathrm{H}$, $\mathrm{COCH}_{2} \mathrm{Br}$ ), 4.02-4.04 (s, J= 8.4 Hz, $1 \mathrm{H}, 2$-adamantane $\mathrm{H}$ ) ppm. $\mathrm{N}$-(2-Adamantanyl)-2-[(3,7-dimethylocta-2,6-dien-1-yl)amino]acetamide (8)

Bromoacetamide 7 ( $1.05 \mathrm{~g}, 3.86 \mathrm{mmol})$ in dry THF $(20 \mathrm{~mL})$ was added dropwise at $0{ }^{\circ} \mathrm{C}$ to a stirred solution of geranylamine 4 (590 mg, $3.86 \mathrm{mmol}$ ) and triethylamine (390 mg, $3.86 \mathrm{mmol}$ ) in dry THF $(30 \mathrm{~mL})$. The stirring continued for $48 \mathrm{~h}$ at room temperature. Then the aqueous phase was extracted twice with DCM, the combined organic extracts were evaporated in vacuo, and the crude product was purified through column chromatography using a) diethyl ether $/ n$-hexane (1:1), b) $\mathrm{CHCl}_{3} / \mathrm{MeOH}$ (9:1) as solvent systems. The acetamide $\mathbf{8}$ was obtained as a pale-yellow oil; yield $1.14 \mathrm{~g}(86 \%) .{ }^{1} \mathrm{H} \mathrm{NMR}\left(\mathrm{CDCl}_{3}, 400 \mathrm{MHz}\right): \delta$ $=1.59(\mathrm{~s}, 3 \mathrm{H}, 8-\mathrm{H}), 1.62\left(\mathrm{~s}, 3 \mathrm{H}, 7-\mathrm{CH}_{3}\right), 1.67\left(\mathrm{~s}, 3 \mathrm{H}, 3-\mathrm{CH}_{3}\right)$, 1.65-1.90 (m, $14 \mathrm{H}, 1,3,4,5,6,7,8,9,10$-adamantane $\mathrm{H}), 2.02-$ 2.07 ( $\mathrm{m}, 4 \mathrm{H}, 4-\mathrm{H}, 5-\mathrm{H}), 3.17$ (s, $\left.2 \mathrm{H}, \mathrm{COCH}_{2} \mathrm{NH}\right), 3.31$ (d, $J=7.4$ $\mathrm{Hz}, 2 \mathrm{H}, 1-\mathrm{H}), 3.18(\mathrm{~s}, 1 \mathrm{H}, 2$-adamantane $\mathrm{H}), 4.01(\mathrm{~s}, 1 \mathrm{H}, \mathrm{NH}-$ adamantane), $5.05(\mathrm{~m}, 1 \mathrm{H}, 6-\mathrm{H}), 5.25$ (t, $J=7.4 \mathrm{~Hz}, 1 \mathrm{H}, 2-\mathrm{H}$ ), $7.04\left(\mathrm{~s}, 1 \mathrm{H}, \mathrm{NH}\right.$-geranyl) ppm. Hydrochloride salt: ${ }^{13} \mathrm{C}$ NMR $\left(\mathrm{CD}_{3} \mathrm{OD}, 100 \mathrm{MHz}\right): \delta=17.9\left(3-\mathrm{CH}_{3}\right), 18.7(8-\mathrm{C}), 26.7\left(7-\mathrm{CH}_{3}\right)$, 28.0 (5-C), 29.5 (5,7-adamantane C), 33.4 (4,9-adamantane C), 34.1 (1,3-adamantane C), 39.1 (8,10-adamantane C), 39.4 (6-adamantane C), 41.7 (4-C), 55.7 (1-C), $56.2\left(\mathrm{COCH}_{2} \mathrm{NH}\right), 56.9$ 
(2-adamantane C), 114.1 (2-C), 125.3 (6-C), 134.1 (7-C), 151.9 (3-C), $166.0(\mathrm{C}=0)$ ppm. HRMS (ESI-TOF $(+)): m / z[\mathrm{M}+\mathrm{H}]^{+}$calcd for $\left[\mathrm{C}_{22} \mathrm{H}_{37} \mathrm{~N}_{2} \mathrm{O}\right]^{+}:$345.2906; found: 345.2888 .

2-Bromo- $\mathbf{N}$-(3,7-dimethylocta-2,6-dien-1-yl)acetamide (11) Bromoacetyl chloride $(1.13 \mathrm{~g}, 7.18 \mathrm{mmol})$ in DCM $(17 \mathrm{~mL})$ was added dropwise at $0{ }^{\circ} \mathrm{C}$ to a vigorously stirred solution of geranylamine $4(1 \mathrm{~g}, 6.53 \mathrm{mmol})$ in DCM $(30 \mathrm{~mL})$ and aqueous $\mathrm{K}_{2} \mathrm{CO}_{3}$ $\left(1.14 \mathrm{~g}, 10 \mathrm{~mL} \mathrm{H}_{2} \mathrm{O}\right)$. The mixture was stirred for $24 \mathrm{~h}$, and then the aqueous was extracted twice with DCM. The combined organic extracts were concentrated in vacuo, and the crude product was dissolved in diethyl ether. The solution was washed with $\mathrm{NaHCO}_{3} 10 \% \mathrm{w} / \mathrm{v}, \mathrm{H}_{2} \mathrm{O}, \mathrm{HCl} 3 \% \mathrm{v} / \mathrm{v}, \mathrm{H}_{2} \mathrm{O}$, and brine. The solvent was then evaporated in vacuo, and the product was filtered through silica gel using $n$-hexane/EtOAc (3:1) as eluent to afford $1.64 \mathrm{~g}$ of bromoacetamide (11) as a yellow solid (91\% yield). ${ }^{1} \mathrm{H}$ NMR $\left(\mathrm{CDCl}_{3}, 400 \mathrm{MHz}\right): \delta=1.60(\mathrm{~s}, 3 \mathrm{H}, 8-\mathrm{H}), 1.68(\mathrm{~s}, 6$ $\left.\mathrm{H}, 7-\mathrm{CH}_{3}, 3-\mathrm{CH}_{3}\right), 2.00-2.12(\mathrm{~m}, 4 \mathrm{H}, 4-\mathrm{H}, 5-\mathrm{H}), 3.88(\mathrm{~s}, 2 \mathrm{H}$, $\left.\mathrm{COCH}_{2} \mathrm{Br}\right), 5.06(\mathrm{t}, J=7.0 \mathrm{~Hz}, 1 \mathrm{H}, 6-\mathrm{H}), 5.19(\mathrm{t}, J=7.0 \mathrm{~Hz}, 1 \mathrm{H}, 2-$ H) $\mathrm{ppm}$.

2-[(2-Adamantyl)amino]- $N$-(3,7-dimethylocta-2,6-dien-1yl)acetamide (12)

Bromoacetamide 11 (960 mg, $3.50 \mathrm{mmol})$ in dry THF (20 mL) was added dropwise at $0{ }^{\circ} \mathrm{C}$ to a stirred solution of 2-adamantanamine (6) ${ }^{26}(530 \mathrm{mg}, 3.50 \mathrm{mmol})$ and triethylamine (354 mg, $3.50 \mathrm{mmol})$ in anhydrous THF $(30 \mathrm{~mL})$, and stirring was continued for $48 \mathrm{~h}$ at room temperature. The aqueous phase was extracted twice with DCM, the combined organic extracts were evaporated in vacuo, and the crude product was purified by column chromatography, eluting with a) diethyl ether $/ n$-hexane (1:1), b) $\mathrm{CHCl}_{3} / \mathrm{MeOH}$ (9:1). Acetamide 12 was obtained as a yellow oil (870 mg, $72 \%$ yield ). ${ }^{1} \mathrm{H}$ NMR $\left(\mathrm{CDCl}_{3}, 400 \mathrm{MHz}\right): \delta=$ 1.56-1.59 (m, 5 H, 8-H, 4eq,9eq-adamantane H), 1.67 (s, 6 H, 7$\left.\mathrm{CH}_{3}, 3-\mathrm{CH}_{3}\right), 1.67-1.71$ (m, $4 \mathrm{H}, 1,3,6$-adamantane $\left.\mathrm{H}\right), 1.81-1.92$ (m, $6 \mathrm{H}, 4 \mathrm{ax}, 5,7,8 \mathrm{ax}, 9 \mathrm{ax}, 10 \mathrm{ax}$-adamantane $\mathrm{H}), 1.98-2.10$ (m, 4 $\mathrm{H}, 4,5-\mathrm{H}), 2.77$ (s, $1 \mathrm{H}, 2$-adamantane $\mathrm{H}), 3.27$ (s, $1 \mathrm{H}, \mathrm{NHCH}_{2} \mathrm{CO}$ ), $3.43\left(\mathrm{~s}, 1 \mathrm{H}, \mathrm{NHCH}_{2} \mathrm{CO}\right), 3.84-3.89(\mathrm{~m}, 2 \mathrm{H}, 1-\mathrm{H}), 5.07(\mathrm{~m}, 1 \mathrm{H}, 6-$ $\mathrm{H}), 5.19(\mathrm{~m}, 1 \mathrm{H}, 2-\mathrm{H}) \mathrm{ppm} .{ }^{13} \mathrm{C} \mathrm{NMR}\left(\mathrm{CD}_{3} \mathrm{OD}, 100 \mathrm{MHz}\right): \delta=17.2$ (3- $\left.\mathrm{CH}_{3}\right), 18.6(8-\mathrm{C}), 26.7\left(7-\mathrm{CH}_{3}\right), 28.3(5-\mathrm{C}), 28.9$ (5-adamantane C), 29.2 (7-adamantane C), 31.6 (4,9-adamantane C), 32.1 (1,3-adamantane C), 38.7 (8,10-adamantane C), 38.8 (6-adamantane C), $39.3(4-\mathrm{C}), 41.4(1-\mathrm{C}), 48.0\left(\mathrm{NHCH}_{2} \mathrm{CO}\right), 65.8$ (2adamantane C), 121.5 (2-C), $125.8(6-C), 133.4(7-C), 141.9$ (3C), $166.6(\mathrm{C}=\mathrm{O})$ ppm. HRMS (ESI-TOF $(+)): \mathrm{m} / z[\mathrm{M}+\mathrm{H}]^{+}$calcd for $\left[\mathrm{C}_{22} \mathrm{H}_{37} \mathrm{~N}_{2} \mathrm{O}\right]^{+}$: 345.2906 ; found: 345.2897 .

$N$-(2-Adamantanyl)- $N^{\prime}$-(3,7-dimethylocta-2,6-dien-1-yl)ethane-1,2-diamine $(\mathrm{SQ109}, 10)$

Acetamide $8(870 \mathrm{mg}, 2.52 \mathrm{mmol})$ in dry DCM $(11 \mathrm{~mL})$ was stirred at $0-5{ }^{\circ} \mathrm{C}$ for 15 min under an argon atmosphere. Freshly distilled trimethylsilyl chloride ( $328 \mu \mathrm{L}, 3.02 \mathrm{mmol}$ ) was then added at the same temperature, and the mixture was stirred for another $15 \mathrm{~min}$. A suspension of $\mathrm{LiAlH}_{4}(134 \mathrm{mg}, 3.53 \mathrm{mmol})$ in a small quantity of anhydrous THF was added between $-10{ }^{\circ} \mathrm{C}$ and $0{ }^{\circ} \mathrm{C}$, and the stirring was continued for $2.5 \mathrm{~h}$ at the same temperature. The mixture was then treated with $\mathrm{NaOH} 10 \%$, the resulting inorganic precipitate was filtered off, the organic phase was separated, and the aqueous phase was extracted twice with DCM. The combined organic extracts were evaporated in vacuo, and the crude product was dissolved in DCM and washed with brine. After separation and evaporation of the solvent, the crude product was purified by column chromatography using either $\mathrm{CHCl}_{3} / \mathrm{MeOH}$ (9:1) or $\mathrm{CHCl}_{3} / \mathrm{MeOH} / \mathrm{NH}_{3}$ (88:10:2), eluents, to afford diamine $\mathbf{1 0}$ as a pale-yellow oil; yield $260 \mathrm{mg}(31 \%)$.

Acetamide $12(290 \mathrm{mg}, 0.84 \mathrm{mmol})$ in dry DCM $(4 \mathrm{~mL})$ was stirred at $0-5{ }^{\circ} \mathrm{C}$ for 15 min under an argon atmosphere. Freshly distilled trimethylsilyl chloride $(110 \mu \mathrm{L}, 1.01 \mathrm{mmol})$ was then added at the same temperature, and the mixture was stirred for a further $15 \mathrm{~min}$. A suspension of $\mathrm{LiAlH}_{4}(45 \mathrm{mg}, 1.18 \mathrm{mmol})$ in a small quantity of THF was added at $-10^{\circ} \mathrm{C}$ to $0{ }^{\circ} \mathrm{C}$, and stirring was continued for $2.5 \mathrm{~h}$ at the same temperature. The mixture was then treated with $10 \%$ aqueous $\mathrm{NaOH}$, the resulting inorganic precipitate was filtered off, the organic phase was separated, and the aqueous phase was extracted twice with DCM. The combined organic extracts were evaporated in vacuo, and the crude product was dissolved in DCM and washed with brine. After separation and evaporation of the solvent, the crude product was purified by column chromatography using either $\mathrm{CHCl}_{3} / \mathrm{MeOH}$ (9:1) or $\mathrm{CHCl}_{3} / \mathrm{MeOH} / \mathrm{NH}_{3}$ (88:10:2) as eluents to afford diamine 10 as a pale-yellow oil (111 mg, 38\% yield). ${ }^{1} \mathrm{H}$ $\operatorname{NMR}\left(\mathrm{CDCl}_{3}, 400 \mathrm{MHz}\right): \delta=1.47$ (d, $J=12 \mathrm{~Hz}, 2 \mathrm{H}, 4$ eq,9eq-adamantane $\mathrm{H}), 1.59(\mathrm{~s}, 3 \mathrm{H}, 8-\mathrm{H}), 1.64\left(\mathrm{~s}, 3 \mathrm{H}, 7-\mathrm{CH}_{3}\right), 1.67(\mathrm{~s}, 3 \mathrm{H}$, 3- $\left.\mathrm{CH}_{3}\right), 1.70-1.85$ ( $\mathrm{m}, 10 \mathrm{H}, 1,3,5,6,7,8,10$-adamantane $\left.\mathrm{H}\right), 1.95$ (d, $J=12 \mathrm{~Hz}, 2 \mathrm{H}, 4 \mathrm{ax}, 9 \mathrm{ax}$-adamantane $\mathrm{H}), 1.98-2.02(\mathrm{~m}, 2 \mathrm{H}, 5-$ H), 2.06-2.11 (m, $2 \mathrm{H}, 4-\mathrm{H}), 2.71(\mathrm{~s}, 1 \mathrm{H}, 2-\mathrm{H}), 2.74(\mathrm{~s}, 4 \mathrm{H}$, $\mathrm{NHCH}_{2} \mathrm{CH}_{2} \mathrm{NH}$ ), 3.25 (d, $\left.J=7.0 \mathrm{~Hz}, 2 \mathrm{H}, 1-\mathrm{H}\right), 5.09(\mathrm{~m}, 1 \mathrm{H}, 6-\mathrm{H})$, $5.26(\mathrm{~m}, 1 \mathrm{H}, 2-\mathrm{H}) \mathrm{ppm} .{ }^{13} \mathrm{C} \mathrm{NMR}\left(\mathrm{CDCl}_{3}, 100 \mathrm{MHz}\right): \delta=16.5$ $\left(\mathrm{CH}_{3}-3\right), 18.0$ (8-C), 26.0 (7- $\left.\mathrm{CH}_{3}\right), 26.8$ (5-C), 27.9 (5-adamantane C), 28.1 (7-adamantane C), 31.7 (4,9-adamantane C), 32.5 (1,3-adamantane $\mathrm{C}), 37.9$ (8,10-adamantane $\mathrm{C}), 38.3$ (6-adamantane $\mathrm{C}), 40.2(4-\mathrm{C}), 46.8(1-\mathrm{C}), 47.4\left(\mathrm{NHCH}_{2} \mathrm{CH}_{2} \mathrm{NH}\right.$-geranyl), $49.8\left(\mathrm{NHCH}_{2} \mathrm{CH}_{2} \mathrm{NH}\right.$-geranyl), 62.3 (2-adamantane $\mathrm{C}$ ), 121.9 (2C), 123.3 (6-C), 131.9 (7-C), 137.9 (3-C) ppm. HRMS (ESI-TOF $(+)): m / z[M+H]^{+}$calcd for $\left[\mathrm{C}_{22} \mathrm{H}_{39} \mathrm{~N}_{2}\right]^{+}: 331.3108$; found: 331.3101 . 